\title{
Evaluation of the productivity and rooting of cuttings of ten Eucalyptus clones
}

\author{
Ortega-Ramírez, Marynor E. ${ }^{1^{*}}$; Castro-Osorio, Adrian ${ }^{3}$; González-Cortés, Nicolás ${ }^{2}$; Prados-Coronado, Jesús ${ }^{3}$ \\ ${ }^{1}$ Universidad Autónoma de Chiapas, Facultad Maya de Estudios Agropecuario, Catazaja, \\ Chiapas, México, C.P. 29980. ²Universidad Juárez Autónoma de Tabasco, Tenosique. ${ }^{3}$ Instituto \\ Técnológico de las Choapas. Choapas, Veracruz. \\ *Corresponding author: marynor.ortega@gmail.com
}

\begin{abstract}
Objective: evaluating the productivity of mother plants and the rooting percentage of cuttings of Eucalyptus grandis, Eucalyptus urophylla and Eucalyptus urograndis.
\end{abstract}

Design: Ten clones of each species were evaluated in a clonal miniature garden in a gutter system fitted with drip irrigation. Results: The assessed number of sprouts and viable cuttings variables registered high significant differences $(P<0.0001)$ between clones: UP1 (17,947 shoots and 34.05 viable cuttings), UG2 (12,120 shoots and 22.96 viable cuttings) and G2 $(10,254$ shoots and 23.96 viable cuttings). Regard the measured parameters in the irrigation water, the average values of EC $0.5 \mathrm{mS} / \mathrm{cm}$ and $\mathrm{pH} 5$ to 7 were obtained. The stem cuttings established in the module had high significant differences $(P<0.0001)$ in terms of the rooting percentage. Three clones were superior, the best of which, clone G2, reports $78.58 \%$ rooting, which developed in environmental conditions of relative humidity greater than $80 \%$ and temperature between $25-30^{\circ} \mathrm{C}$.

Findings/conclusions: With the obtained values from the measured variables, a rooting productivity projection was carried out considering a 54 mother plants $/ \mathrm{m}^{2}$ density, resulting in a minimum average annual production of viable cuttings from 10,000 to 27,000 depending on the clone, with 2,000 to 18,000 cuttings with rooting possibilities per square meter.

Keywords: Asexual propagation, Clonal miniature garden, plant growth regulators.

\section{INTRODUCTION}

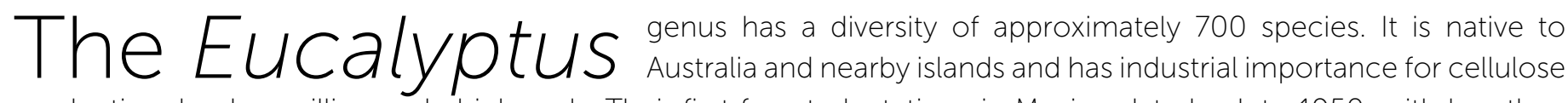
production, lumber milling and chipboards. Their first forest plantations in Mexico date back to 1950, with less than 7,000 hectares planted with broadleaf species, mainly eucalyptus. The "Pulsar" company had a eucalyptus plantation with a 300,000 hectares area at Emiliano Zapata, Tabasco, Mexico (Martínez et al., 2006). The objective of this work was to evaluate the productivity of mother plants and rooting percentage of cuttings of Eucalyptus grandis, Eucalyptus urophylla and Eucalyptus urograndis.

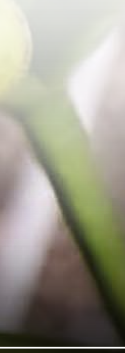

Agroproductividad: Vol. 13, Núm. 9, septiembre. 2020. pp: 57-62. Recibido: mayo, 2020. Aceptado: agosto, 2020.
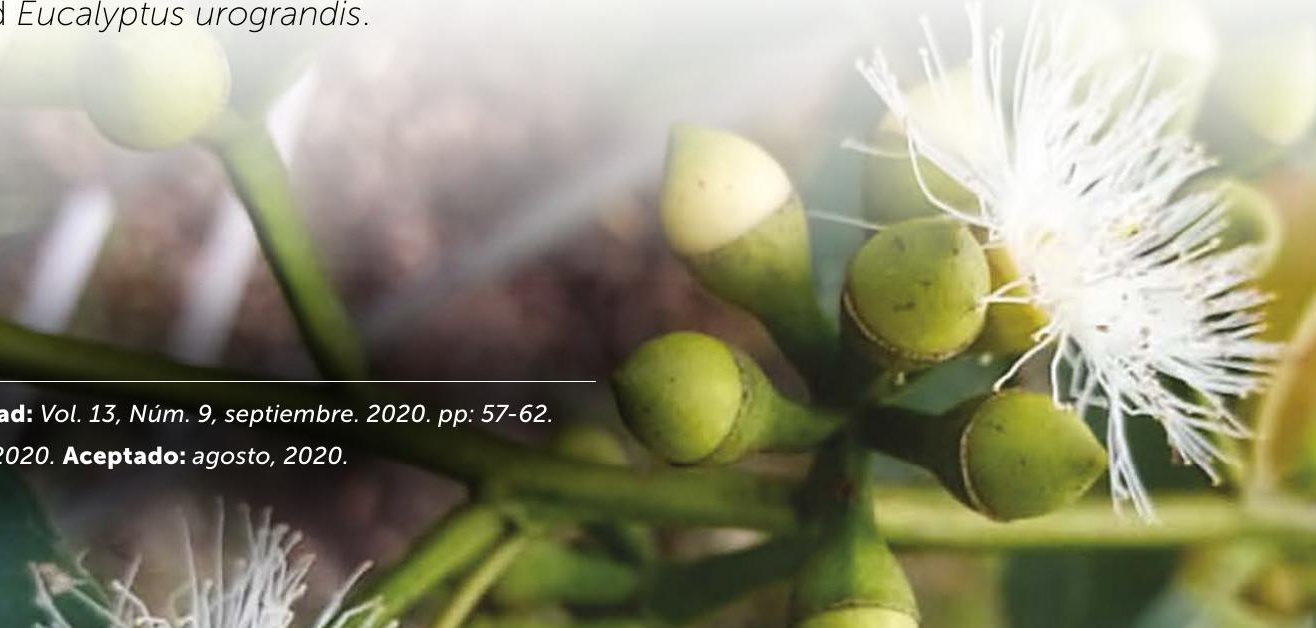


\section{MATERIALS AND METHODS Study Area Location}

The study was developed in a nursery of the Proplanse S.A. de CV company, located at km 12.5 of the BaláncanEl Triunfo highway, Balancán, Tabasco, Mexico (UTM coordinates, zone 15 Q $659601 \mathrm{~m} \mathrm{E}$ and $1976492 \mathrm{~m} \mathrm{~N}$ ) where a clonal miniature garden with mother plants of the Eucalyptus genus was established.

\section{Background of the evaluated clones}

In this research, ten different clones of Eucalyptus grandis (1), Eucalyptus urophylla (8) and Eucalyptus urograndis (1) obtained from selected trees in operational plantations and trials because of their outstanding productivity and economic interest, the characteristics of diameter and height of these trees are summarized in Table 1.

The clone capture process consisted of knocking down selected trees to promote sprouts emission, from these, vegetative material was collected. The cuttings were rooted and multiplied to obtain mother plants of the clonal miniature garden. A total sample population of $\mathrm{n}=130$ individuals as an experimental unit (Table 2) was evaluated.

An analysis of variance (ANOVA) was performed on the assessed variables, the number of regrowths, number of viable cuttings and survival percentage, the value of the F statistics and its significance are shown. With mean comparison analysis with 5\% TUKEY test to determine homogeneous or heterogeneous groups. For this, the STATISTIX 10 statistical software was used.

\section{Mother plant productivity}

The mother plants productivity data recollection consisted of counting the sprouts obtained per vegetative unit sampled from each clone, later the viable cuttings made from these sprouts were counted.

\begin{tabular}{|c|c|c|c|c|c|}
\hline Number & Material & Species & Source & Diameter (cm) & Height (m) \\
\hline 1 & UP1 & E. grandis & Arboretum, Balancán & 47 & 31 \\
\hline 2 & G2 & E. urophylla & Arboretum, Balancán & 57 & 35 \\
\hline 3 & UG2 & E. urograndis & Arboretum, Balancán & 53 & 36 \\
\hline 4 & PC11 & E. urophylla & V. Carranza, Huimanguillo & 53 & 41 \\
\hline 5 & PC12 & E. urophylla & V. Carranza, Huimanguillo & 60 & 39 \\
\hline 6 & PC21 & E. urophylla & V. Carranza, Huimanguillo & 60 & 42 \\
\hline 7 & PC16 & E. urophylla & V. Carranza, Huimanguillo & 59 & 38 \\
\hline 8 & PC30 & E. urophylla & V. Carranza, Huimanguillo & 54 & 41 \\
\hline 9 & PC37 & E. urophylla & V. Carranza, Huimanguillo & 53 & 52 \\
\hline 10 & PC31 & E. urophylla & V. Carranza, Huimanguillo & 53 & 39 \\
\hline
\end{tabular}

\begin{tabular}{c|c|l|l|l|r}
\multicolumn{2}{c}{ Table 2. Sample size of the experimental unit per evaluated clone. } \\
Number & Clone & \multicolumn{1}{|c|}{ Species } & \multicolumn{1}{|c}{ Source } & N & (n) \\
\hline 1 & UP1 & E. grandis & Arboretum, Balancán & 38 & 15 \\
\hline 2 & G2 & E. urophylla & Arboretum, Balancán & 36 & 15 \\
\hline 3 & UG2 & E. urograndis & Arboretum, Balancán & 66 & 15 \\
\hline 4 & PC11 & E. urophylla & V. Carranza, Huimanguillo & 180 & 15 \\
\hline 5 & PC12 & E. urophylla & V. Carranza, Huimanguillo & 44 & 15 \\
\hline 6 & PC21 & E. urophylla & V. Carranza, Huimanguillo & 48 & 15 \\
\hline 7 & PC16 & E. urophylla & V. Carranza, Huimanguillo & 78 & 15 \\
\hline 8 & PC30 & E. urophylla & V. Carranza, Huimanguillo & 5 & 5 \\
\hline 9 & PC37 & E. urophylla & V. Carranza, Huimanguillo & 5 & 5 \\
\hline 10 & PC31 & E. urophylla & V. Carranza, Huimanguillo & 341 & 15 \\
\hline Total & & & & 841 & 130
\end{tabular}




\begin{tabular}{|c|c|c|c|c|c|c|}
\hline \multicolumn{7}{|c|}{ Evaluation } \\
\hline Clone & I & II & III & IV & V & Average \\
\hline UP1 & 19 & 21 & 21 & 20 & 21 & 20 \\
\hline G2 & 20 & 17 & 22 & 20 & 20 & 20 \\
\hline UG2 & 21 & 20 & 22 & 17 & 42 & 24 \\
\hline PC11 & 31 & 21 & 19 & 16 & 40 & 25 \\
\hline PC12 & 21 & 21 & 23 & 20 & 36 & 24 \\
\hline PC21 & 22 & 21 & 22 & 20 & 37 & 24 \\
\hline PC16 & 18 & 21 & 24 & 24 & 28 & 23 \\
\hline PC30 & 17 & 22 & 24 & 24 & 29 & 23 \\
\hline PC37 & 17 & 22 & 24 & 24 & 26 & 23 \\
\hline PC31 & 19 & 21 & 26 & 22 & 24 & 22 \\
\hline \multicolumn{6}{|c|}{ General average } & 23 \\
\hline
\end{tabular}

Table 3 shows the number of days elapsed between each harvest per clone, obtaining a $23 \mathrm{~d}$ general average.

\section{Growth regulator application and establishment of stakes}

For the stimulation of adventitious roots in the cuttings made from the clonal miniature garden, a growth regulator treatment was carried out using exogenous auxins, in this case, AIB (Indole-3-butyric acid) in its RADIXTM 1500 commercial presentation, formulated as an impregnable powder with $0.15 \%$ as the active ingredient.

\section{Irrigation Water Characterization}

The management area for cuttings production has evolved in such a way that the spacing of the mother plants has been reduced. Higashi et al. (2004) mention the types of production systems and the distances between plants: field clonal garden $(0.5 \times 0.5 \mathrm{~m})$, clonal miniature garden in gutters on a sand substrate $(0.1 \times 0.1 \mathrm{~m})$ with drip irrigation system, clonal garden in 8 $\mathrm{L}$ plastic containers and mini clonal fiberglass garden $(0.1 \times 0.1 \mathrm{~m})$. Higashi et al. (2002) point out that there is no nutrient solution for all plant species under growing conditions, the nutrients necessary for development are the same, but the amounts extracted differ between and within species. One of the factors determining the success of a clonal propagation operational program employing cuttings is the used nutrient solution in the miniature

\begin{tabular}{|c|c|c|c|c|c|c|}
\hline \multirow[b]{2}{*}{ Evaluation } & \multicolumn{2}{|c|}{ Productivity } & \multicolumn{2}{|c|}{$\mathrm{pH}$ water } & \multicolumn{2}{|c|}{ C.E. $(\mathrm{mS} / \mathrm{cm})$} \\
\hline & Sprouts & $\begin{array}{l}\text { Viable } \\
\text { cuttings }\end{array}$ & average & $\begin{array}{l}\text { Deviation } \\
\text { standard }\end{array}$ & average & $\begin{array}{l}\text { Deviation } \\
\text { standard }\end{array}$ \\
\hline I & 8 & 18 & 5.48 & 0.709 & 0.009 & 0.008 \\
\hline ॥ & 7 & 15 & 4.61 & 0.942 & 1.092 & 0.927 \\
\hline III & 11 & 21 & 4.26 & 0.849 & 0.636 & 0.420 \\
\hline IV & 12 & 23 & 3.81 & 0.641 & 0.55 & 0.393 \\
\hline V & 14 & 20 & 3.71 & 0.362 & 0.63 & 0.147 \\
\hline
\end{tabular}

garden; the chemical properties of irrigation water $(\mathrm{pH}$ and Electrical Conductivity) influence the usage of nutritive elements. Silveira et al. (1999) cited by Higashi et al. (2002) recommend that the electrical conductivity should be in the range of 1.25 to $2.3 \mathrm{mS} / \mathrm{cm}$ for a hydroponic clonal miniature garden system and the $\mathrm{pH}$ between 5.8 and 6.0. However, positive results have been obtained with EC and $\mathrm{pH}$ outside these recommended ranges.

\section{RESULTS AND DISCUSSION}

During the evaluation period of the clonal miniature garden, the irrigation water parameters were taken, the values behaving differently in each evaluation (Table 4.).

Table 5 shows the number of viable shoots and cuttings produced by each mother plant.

\section{Number of sprouts}

During the trial period, with respect to the variable number of regrowth, an increasing trend in the amount of regrowth per individual of each clone was noted according to the age of the mother plant: in the evaluation I, the UP1 clone produced an average of 11 regrowths per individual, 21 regrowths produced on average in the intermediate evaluation (III) and the $V$ evaluation with 28 regrowths on average per individual (Figure 1).

A possible response to this effect of increasing the number of regrowth was the nutrition applied in the clonal miniature garden and the effect of the type of pruning carried out in the regrowth crop. From the analysis of variance summarized in Table 5, three homogeneous groups were formed where the best group was constituted by the UP1 clone 


\begin{tabular}{|c|c|c|}
\hline ClonE & Sprouts number & Viable cuttings number \\
\hline UP1 & $17.947^{\mathrm{A}}$ & $34.05^{\mathrm{A}}$ \\
\hline G2 & $10.254^{B C}$ & $23.29^{B}$ \\
\hline UG2 & $12.120^{B}$ & $22.96^{\mathrm{B}}$ \\
\hline PC11 & $7.929^{C D}$ & $12.69^{D}$ \\
\hline $\mathrm{PC} 12$ & $9.296^{B C D}$ & $15.80^{C D}$ \\
\hline PC21 & $9.581^{B C D}$ & $16.59^{C D}$ \\
\hline PC16 & $10.173^{B C}$ & $18.83^{B C}$ \\
\hline PC30 & $8.095^{B C D}$ & $16.43^{B C D}$ \\
\hline PC37 & $9.760^{B C D}$ & $18.72^{B C D}$ \\
\hline PC31 & $6.625^{D}$ & $15.29^{C D}$ \\
\hline $\mathrm{F}$ & 19.78 & 22.00 \\
\hline P-VALUE & $<0.0001$ & $<0.0001$ \\
\hline
\end{tabular}

PC16, PC37, G2 and PC21 were heterogeneous (Table 6). Figure 4 summarizes the analyzed data by clone, the central tendency, and its means.

Wendling etal. (2003) obtained 5 to 7 cuttings per ministain for each collection in higher production, and 1.2 to 3 in a lower production using four Eucalyptus grandis clones. Analysis of variance percentage of rooting

The results of the analysis of variance for the rooting percentage of the cuttings made of the mini garden are shown in Table 6 , the values of $F$ and their significance degree, with $P<0.0001$ showing highly significant differences. For verification, a Tukey's multiple comparison test was carried out (Table 6. Analysis of variance). Two homogeneous groups superior to the others were formed, where clone G2 reported $78.58 \%$

(A) with an average of 17.95 sprouts, followed by the UG2 clone with 12.12 sprouts (B) and group D constituted For clone PC 31 with only 6.36 sprouts, the other clones were heterogeneous between $B$, $C$ and D. Figure 2 shows the measured variables, observing clones such as G2 (median 10 sprouts), PC12 (median 9), PC21 (median 9) and PC31 (median 8), the lower whisker (0) indicate that during the evaluation period there were biases in some individuals and no regrowth was obtained.

\section{Viable stem cuttings}

Overall, obtaining viable stem cutting during the productivity evaluation behaved as follows: In the first evaluation, 18 viable stem cutting were obtained on average, 15 stem cutting in the second evaluation, and 21 viable stem cutting in the third evaluation and 23 viable stem cutting on average in the fourth evaluation which ended in December with 20 viable stem cutting. Figure 3 shows the behavior and trend of the number of regrowth variable of each clone according to the progress of the evaluation.

Three homogeneous groups formed in which the best group was the UP1 clone with an average of 34.05 viable cuttings (A), followed by the UG2 clone with average 22.96 viable cuttings (B) and group $C$ by the PC12 clone (14.96 viable cuttings), PC31 (14.68 viable cuttings), PC30 (13.80 viable cuttings) and PC11 (11.84 viable cuttings); clones

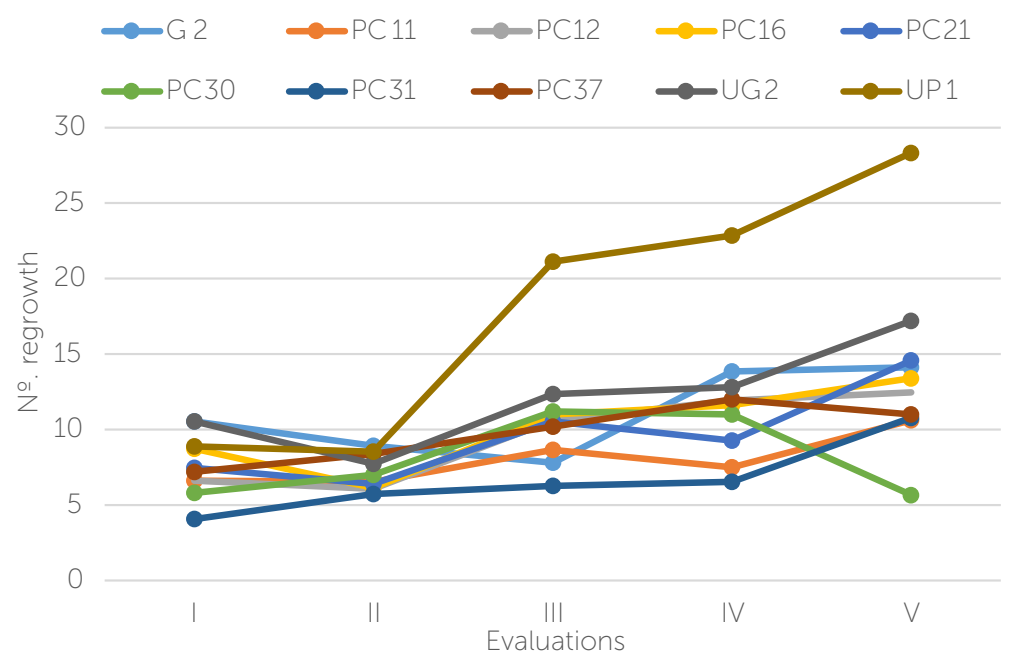

Figure 1. Average behavior of sprouts per clone according to the data collected during the evaluation period.

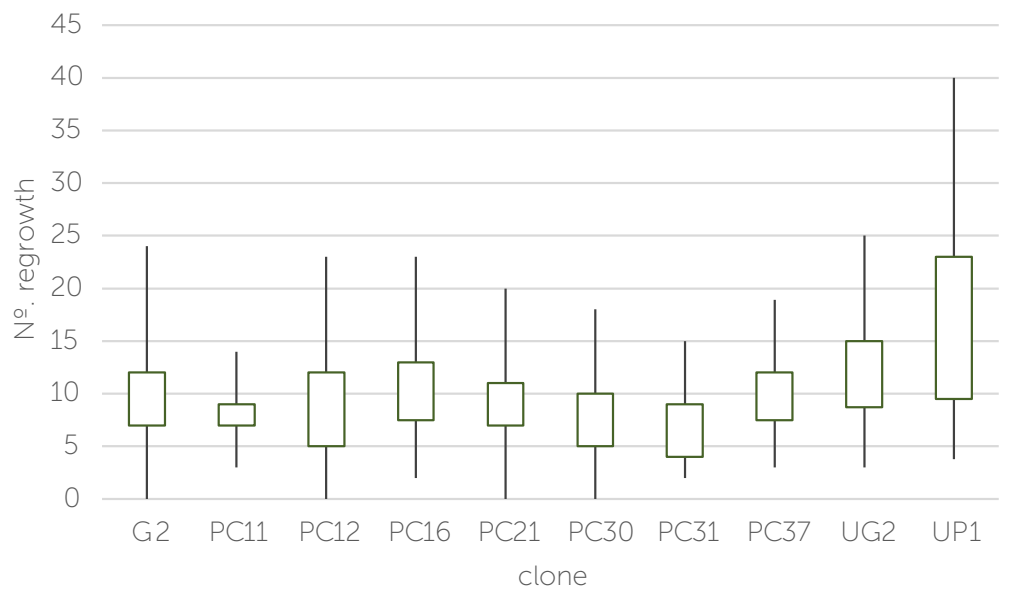

Figure 2. Number of sprouts per clone. Outliers represented by asterisks (*) 


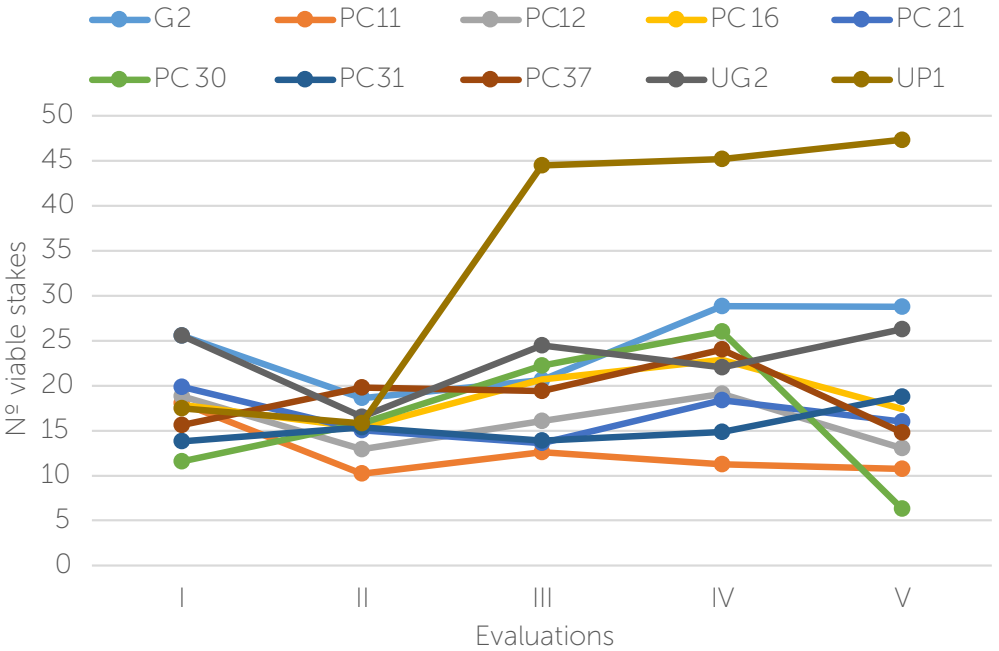

Figure 3. Behavior of the variable per clone for each evaluation.

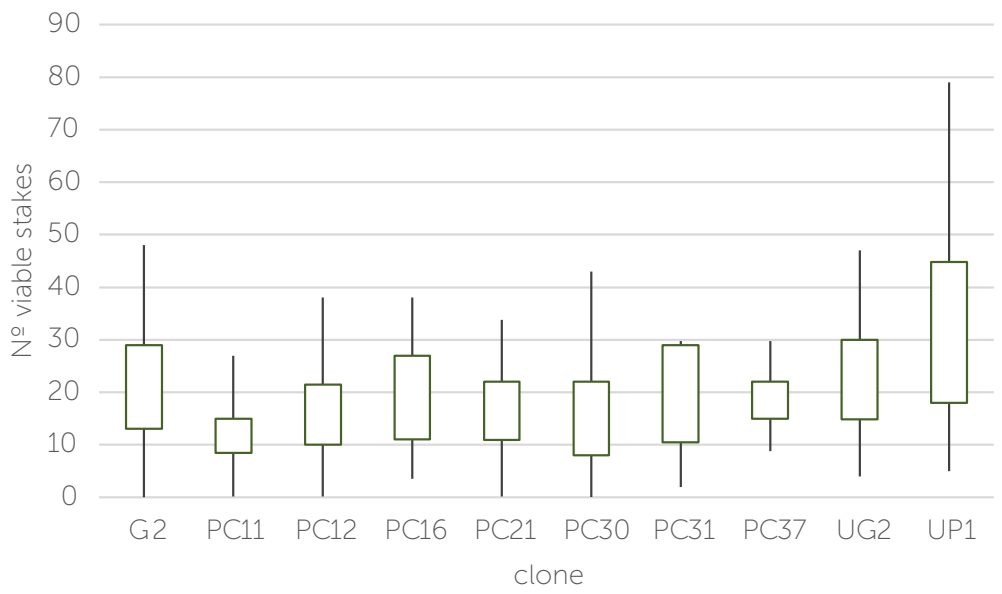

Figure 4. Box plot number of viable cuttings per clone

\begin{tabular}{|c|c|c|}
\hline \multirow{2}{*}{ Clone } & \multicolumn{2}{|c|}{ Module } \\
\hline & $\%$ rooting & CV (\%) \\
\hline UP1 & $68.75^{A B}$ & 22.16 \\
\hline G2 & $78.58^{A}$ & 13.44 \\
\hline UG2 & $68.00^{A B}$ & 29.70 \\
\hline PC11 & $46.44^{A B C}$ & 43.57 \\
\hline PC12 & $34.39^{B C}$ & 41.85 \\
\hline PC21 & $33.32^{B C}$ & 56.67 \\
\hline PC16 & $19.34^{C}$ & 70.15 \\
\hline PC30 & $15.67^{C}$ & 78.53 \\
\hline PC37 & $30.36^{C}$ & 44.05 \\
\hline PC31 & $42.76^{A B C}$ & 59.59 \\
\hline F & 7.96 & \\
\hline$p$-value & $<0.0001$ & \\
\hline
\end{tabular}

of sprouts and rooted cuttings. According to the obtained results and the criteria of a clonal operative program, clone G2 reported the adequate rooting percentage; However, UP1 and UG2 clones present an average close to the adequate, therefore, these three clones are suitable to start the clonal operating program of the Proplanse company; the values of the variables in the rooting phase are within the recommended range for clonal propagation utilizing cuttings.

\section{CONCLUSIONS}

rooting (A), followed by clone PC37 (30.36\%), PC30 (19.58\%) and PC16 (19.34), in the heterogeneous group (A, B and C) constituted by clones UP1, UG2, PC11, PC31, PC12, PC21 with only 68.75, 68.00, $46.44,42.76,34.39$ and 33.32 percent rooting.

According to Arnold et al. (1991) and Leakey (1985) the second preselection level occurs in clonal propagation, using only those clones with greater than $70 \%$ rooting capacities and according to the data obtained, the clones G2, UG2 and UP1 would pass (Figure 5).

Monitoring of $\mathrm{pH}$ and the irrigation water C.E. allows to assess their values and, where appropriate, correct them to adapt them to 0.5 $\mathrm{mS} / \mathrm{cm} \mathrm{EC}$ and $\mathrm{pH} 5$ to 7 , due to the relation with the mother plants intake, reflected in the number
The implementation of a clonal Eucalyptus miniature garden system with high cuttings productivity and

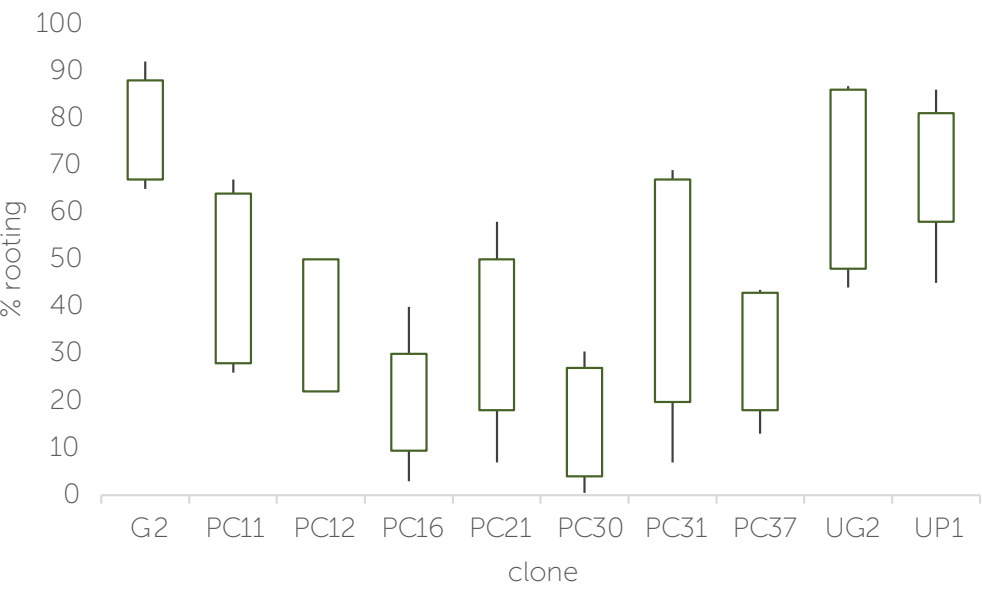

Figure 5. Rooting Percentage per clone, obtaining three highly significant clones; UG, UG2 and UP1 
good rooting capacity for seedling production is feasible. According to the analysis of the parameters measured in the clonal miniature garden, there is a relationship between viable cuttings and the number of shoots according to the clone, in such a way that three superior clones were identified (UP1 (17,947 shoots and 34.05 viable cuttings), UG2 (12,120 shoots and 22.96 viable cuttings) and G2 (10,254 shoots and 23.96 viable cuttings).

\section{REFERENCES}

Borges, S. R., Xavier, A., Oliveira, L. S., Melo, L. A., \& Rosado, A. M. (2011). Enraizamento de miniestacas de clones híbrido de Eucalyptus globulus. Resvista Árvore,35: 3, :425-434.

Carpineti, L. (1996). Propagación agámica de Eucalyptus. XI Jornada Forestales de entre Rios, 17-31.

CONAFOR. (2011). Estudio de Caso; Plantaciones Forestales del Sureste (PROPLANSE). En CONAFOR, Situación Actual y Perspectivas de las Plantaciones Forestales Comerciales en México. (págs. 342-357). México: CONAFOR

CONAFOR. (2011). Rendimiento e incremento esperados por especies de interés a nivel nacional. En CONAFOR, Situación Actual y Perspectivas de las Plantaciones Forestales Comerciales en México (págs. 28-38). México: CONAFOR.

CONAFOR. (2011). Situación Actual y Perspectivas de las Plantaciones Forestales Comerciales en México. México: CONAFOR.

Higashi, E. N., Namita, E., \& Silveira Arruda, R. L. (2004). Fertirrigacao em viveiros de mudas de Eucalyptus e Pinus. RR Agroflorestal, 416-763.

Higashi, E. N., Silveira, R. V., \& Natal Goncalves, A. (2000, Núm. 192). Propagacao vegetativa de Eucalyptus princípios básicos e a sua evolucao no Brasil. IPEF,

Higashi, E., Arruda Silveira, R. L., \& Natal Goncalves, A. (2002). Nutricao e adubacao em minijardim clonal hidroponico. IPEF.

Martínez I Farre, F. X., \& Águila I Sancho, J. F. (2007). El enraizado de esquejes de plantas ornamentales. Horticultura Revista de Industria Distribución y Socioeconomía Hortícola, 9-42.

Ruiz García, R., Vargas Hernández, J. J., Cetina Alcalá, V. M., \& Villegas Monter, Á. (2005). Fecto del ácido indolbutírico (AIB) y tipo de estaca en el enraizado de Gmelina arborea Roxb. Revista Fitotecnia Mexicana,28:4, 319-326.

Ruiz, R. M. (2005). Micropropagación clonal in vitro en Eucalyptus grandis y E. urophylla. Ra Ximhai, 111-130.

Wendling, I., \& Xavier, A. (2003). Miniestaquia seriada no rejuvenescimento de clones de Eucalyptus. Pesquisa Agropecuária Brasileira, 38:4, 475-480

Wendling, I., Xavier, A., \& Noguiera de Paiva, H. (2003). Influencia da miniestaquia seriada no vigor de minicepas de clones de Eucalyptus grandis. Revista Árvore, 27:5, 611-618.

Xavier, A., \& Campos Otoni, W. (2009). Aplicacoes da micropropagacao na clonagem de Eucalyptus no Brasil. Agronomía Costarricense, 304-307

Xavier, A., \& Silva, R. L. (2010). Evolucao da silvicultura clonal de Eucalyptus no brasil. Agronomía Costarricense, 94-98. 